\title{
RELATIONSHIP BETWEEN ENSO CYCLES AND FROST EVENTS WITHIN THE PAMPA HÚMEDA REGION
}

\author{
GABRIELA V. MÜLLER ${ }^{\mathrm{a}, *}$, MARIO N. NUÑEZ ${ }^{\mathrm{a}}$ and MARCELO E. SELUCHI ${ }^{\mathrm{b}}$

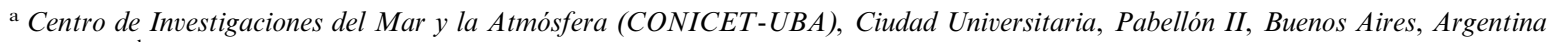 \\ ${ }^{\mathrm{b}}$ Centro de Previsao de Tempo e Estudos Climaticos (CPTEC-INPE), Cachoeira Paulista, Sao Pablo, Brazil
}

Received 22 June 1999

Revised 24 December 1999

Accepted 24 January 2000

\begin{abstract}
The objective of the present paper is to analyse the possible impact of ENSO events on the spatial and the temporal distribution of frost occurrences, within the central region of Argentina. Therefore, the minimum temperature series have been studied for 41 meteorological stations within the Pampa Húmeda region and, for a period of 30 years from 1961 to 1990, exploring possible relationships with El Niño (EN)/La Niña (LN) events and the changes in the Southern Oscillation.

It can be concluded that part of the frost frequency variability within this region is explained by the ENSO cycle. Results indicate that, for at least 1 of the 2 years in which the EN event takes place, the mean number of frost occurrences drops below the climatological value. The low phase of the Southern Oscillation Index (SOI) also coincides with those years for which the number of frost events remained below the total annual mean in all cases, with the year 1965 as an exception. Conversely, during the high phase of the SOI, this number was above the total annual mean for four of the six classified cases. In the particular case of seasonal frost occurrence, it is related to the warm event development state, exhibiting a greater impact during the autumn and winter months, for which the cold event also seems to have influence. Copyright (C) 2000 Royal Meteorological Society.
\end{abstract}

KEY WORDS: El Niño; El Niño-Southern Oscillation; frost frequency; La Niña; Pampa Húmeda region; Southern Oscillation Index

\section{INTRODUCTION}

One of the main sources of low frequency variability of the tropical atmospheric circulation is associated with the El Niño-Southern Oscillation (ENSO). It presents a clear signal over the South American territory at subtropical as well as extratropical latitudes. Several studies show the influence of warm and cold phases of ENSO cycle on the South American climate variability. Some of them are specially concentrated on the effects over the Argentine territory (Pittock, 1980; Karoly, 1989; Barros and Scasso, 1994; Berri, 1996; Ropelewski and Halpert, 1996; Minetti and Vargas, 1997, among others). Most of these studies analyse ENSO effects on precipitation (Barros et al., 1996a; Tanco and Berri, 1996; Grimm, 1997; Vargas et al., 1999), and fewer concentrate on the effects on other variables such as the temperature. In this matter, as shown by Halpert and Ropelewski (1992), the Southern Oscillation (SO) influences the surface temperature at the regional and global scales. In particular, for the central region of South America, these authors indicated that there is a potential SO-temperature relationship. The central region of South America covers the south of Brazil, Paraguay, the eastern half of Bolivia and the north of Argentina for low phase years, while extending farther south during high phase years to include central Argentina, for some months associating lower (higher) temperatures in the eastern Argentina region with the SO positive (negative) phase. These $\mathrm{SO}$-temperature relationships are consistent with the correlation

\footnotetext{
* Correspondence to: CIMA/Dpto. Cs. de la Atmósfera, Pabellón II $2^{\circ}$ Piso-Ciudad Universitaria, 1428, Buenos Aires, Argentina; e-mail: muller@at.fcen.uba.ar
}

Copyright (C) 2000 Royal Meteorological Society 
studies of Aceituno (1988) and Barros et al. (1996b), showing that the temperatures of the subtropical region of South America are significantly correlated with the Southern Oscillation Index (SOI), relating negative phases of the $\mathrm{SO}$ with high temperatures.

The changes in precipitation regimes and the temperature records would, therefore, indicate circulation anomalies in this region. Salles (1998) studied the circulation anomalies over the south of South America, related to the warm and cold phases of ENSO cycle for the period 1972-1983. An interesting conclusion of this study is that the same characteristic synoptic types obtained for each month, for every year and pressure variability, could be explained by their frequency change. In particular, the impact is more important for winters than for summers in southern South America, during El Niño (EN) or La Niña (LN) event years. This is an expected result, as noted by the same author, as the zonal component of the basic flux increases (corresponding to the synoptic situation with characteristics similar to the mean surface pressure field), or increases the meridional flux. The increase of the latitudinal gradient requires a change in the atmospheric circulation toward a balance that is achieved by the means of a transient component in the Southern Hemisphere (van Loon, 1979). In particular, according to this author, a higher (lower) temperature gradient between Pole and Equator exists during Equatorial Pacific warm (cold) event years. Therefore, during ENSO years, two different aspects are to be considered: on one hand, the change in the gradients, and on the other hand, the change of the frequency associated with the principal synoptic types, especially important for winters (Salles, 1998). These aspects suggest the possibility that the cold air intrusions from the south could be influenced and, therefore, affect the number and intensity of frost events.

The objective of this paper is to analyse the influence of EN and LN events, defined by sea-surface temperature (SST) anomalies within Niño 3 region and the SOI, on the frequency and the intensity of frost events in the Pampa Húmeda region, which have a particular importance for the regional economy.

\section{DATA AND METHODOLOGY}

The daily minimum temperature data set used in the present paper corresponds to the period 1961-1990 and to a meteorological station network operated by the Servicio Meteorológico Nacional (SMN) and the Instituto Nacional de Tecnología Agropecuaria (INTA). As frost events are highly conditioned by local factors, the spatial and temporal consistency of the surface temperature data set is required in order to make comparisons between events in the considered region. Therefore, the meteorological stations have been selected following the condition that the percentage of daily minimum temperature data available should be at least $80 \%$, and the percentage of monthly available data for each month of the period March-November for every year should also be higher than $80 \%$. Unfortunately, a more restrictive condition could not be considered due to a number of missing data. The geographical locations of the 41 selected meteorological stations are shown in Figure 1.

In order to study the spatial and temporal distribution, the following variables have been defined:

- Number of frost days as the number of days with minimum temperature lower or equal to $0^{\circ} \mathrm{C}$ relative to total number of days of the considered period and expressed as a percentage.

- Number of days with weak frost as the number of days with minimum temperature within the interval $\left[0^{\circ},-1^{\circ}\right)$; moderate with minimum temperature between $\left[-1^{\circ},-3^{\circ}\right)$ and intense between $\left[-3^{\circ}\right.$, $-10^{\circ}$ ); considering these values relative to the total number of days with available datum and expressing them as percentages.

Annual and seasonal means have been calculated for each variable, for the latter case three periods of three months have been considered: March-April-May (MAM), June-July-August (JJA) and September-October-November (SON). A weighting factor has been used to minimize the error generated by missing data; it was expressed as a function of the number of available data and the season during which they were registered. In all cases, the mean values have been tested using the Student's $t$-test. 




Figure 1. Geographical location of the stations used

Climatological (annual and seasonal) means have also been calculated, their values and corresponding notations are given in Table I. For each day, the ratio between the number of stations with frosts and the total number of stations that, for this day, have available data was evaluated. This ratio has been used to classify the frost events according to the following criterion: if the percentage of stations with frosts is lower than $25 \%$ the event is classified as isolated, partial if the number of cases is between $25 \%$ and $75 \%$, and generalized if the number of cases is greater or equal to $75 \%$. In this case, the criterion used for missing data was to systematically extract them from the sample in those cases in which the classification could have an ambiguous result.

On the other hand, SST within Niño 3 region of the Equatorial Pacific $\left(5^{\circ} \mathrm{S}-5^{\circ} \mathrm{N}, 90^{\circ}-150^{\circ} \mathrm{W}\right)$ and the SOI were considered as representative indices of ENSO. The SST and SOI anomalies were obtained for the periods: MAM, JJA and SON, subtracting from each value the corresponding seasonal mean over the studied period (1961-1990), and dividing the difference by the corresponding standard deviation for the same time period.

Table I. Mean climatological number of frost days (total)

\begin{tabular}{lllll}
\hline & Annual & \multicolumn{3}{l}{ Seasonal } \\
\cline { 3 - 5 } & & MAM & JJA & \multirow{2}{*}{ SON } \\
\hline Total mean (\%) & 6.38 & 2.88 & 19.19 & 3.0 \\
Moderate and intense total mean (\%) & 4.66 & 1.84 & 14.90 & 1.94 \\
\hline
\end{tabular}




\section{CORRELATIONS}

In order to quantitatively study the observed relationship between ENSO events and the number of frost episodes within the Pampa Húmeda region, the corresponding correlation coefficient has been calculated for each considered meteorological station and tested with a Student's $t$-distribution.

\subsection{Seasonal correlations}

\subsubsection{Correlations with SST}

3.1.1.1. Autumn period: The contours of the obtained correlations between the number of autumn frost episodes and the SST anomalies for the same period are given in Figure 2(a). In this figure, it can be seen that there is a relationship between these two variables for a large area within the studied region (shaded area), with statistically significant values $(90 \%)$. The sign of the correlation is negative in all cases (with the exception of three meteorological stations), which indicates that a lower number of frost episodes would occur when the SST anomalies are positive, and a higher number when these anomalies are negative.

3.1.1.2. Winter period: The obtained correlation between the SST anomalies and the number of frost events for winter indicates a significant relationship locally (not regionally). The correlation sign is negative in all cases (with the exception of one station).

3.1.1.3. Spring period: The correlation values for this 3-month period are extremely low for the entire study region.

\subsubsection{Correlations with SOI}

3.1.2.1. Autumn period: The contours of the correlation between the number of autumn frost episodes and the SOI anomalies for the same period are given in Figure 2(b). As seen in this figure, there is a relationship between the two variables for a large area within the study region (shaded area), with statistically significant values $(90 \%)$. The sign of the correlation is positive, in all cases, with the exception of four stations, which indicates that a lower number of frost events would occur when SOI anomalies are negative, and a higher number when these anomalies are positive.

3.1.2.2. Winter period: The obtained correlation indicates, as happens with SST anomalies, that the relationship is not representative regionally but locally; the correlation sign is positive at all but one meteorological station.

3.1.2.3. Spring period: The values for the obtained correlation are extremely low for the entire analysed region.

The results obtained by Aceituno (1988), corresponding to the correlation between a SOI and the temperature for bi-monthly intervals during 1948-1983, indicate an inverse relation for the months of autumn and winter within the region of interest. The values are significant for the period May-June in concordance with the results alluded to here.

When comparing Figure 2(a) and (b), it can be noted that the region in which significant correlations are obtained is the same in both cases, being more disperse in the case of SOI (Figure 2(a)). A more important relationship between the number of frost episodes and SST anomalies is indicated by these results, with an inverse relation for autumn and winter. Therefore, positive (negative) anomalies of the SST are associated with a lower (higher) number of events.

\section{TEMPORAL AND SPATIAL DISTRIBUTION OF THE FROST EVENTS AND THEIR RELATIONSHIP WITH THE ENSO CYCLE}

\subsection{Temporal analysis}

Among the low frequency perturbations that occur with certain periodicity, the most notable is the ENSO cycle related because of its importance at the global scale (Horel and Wallace, 1981) and its relative 


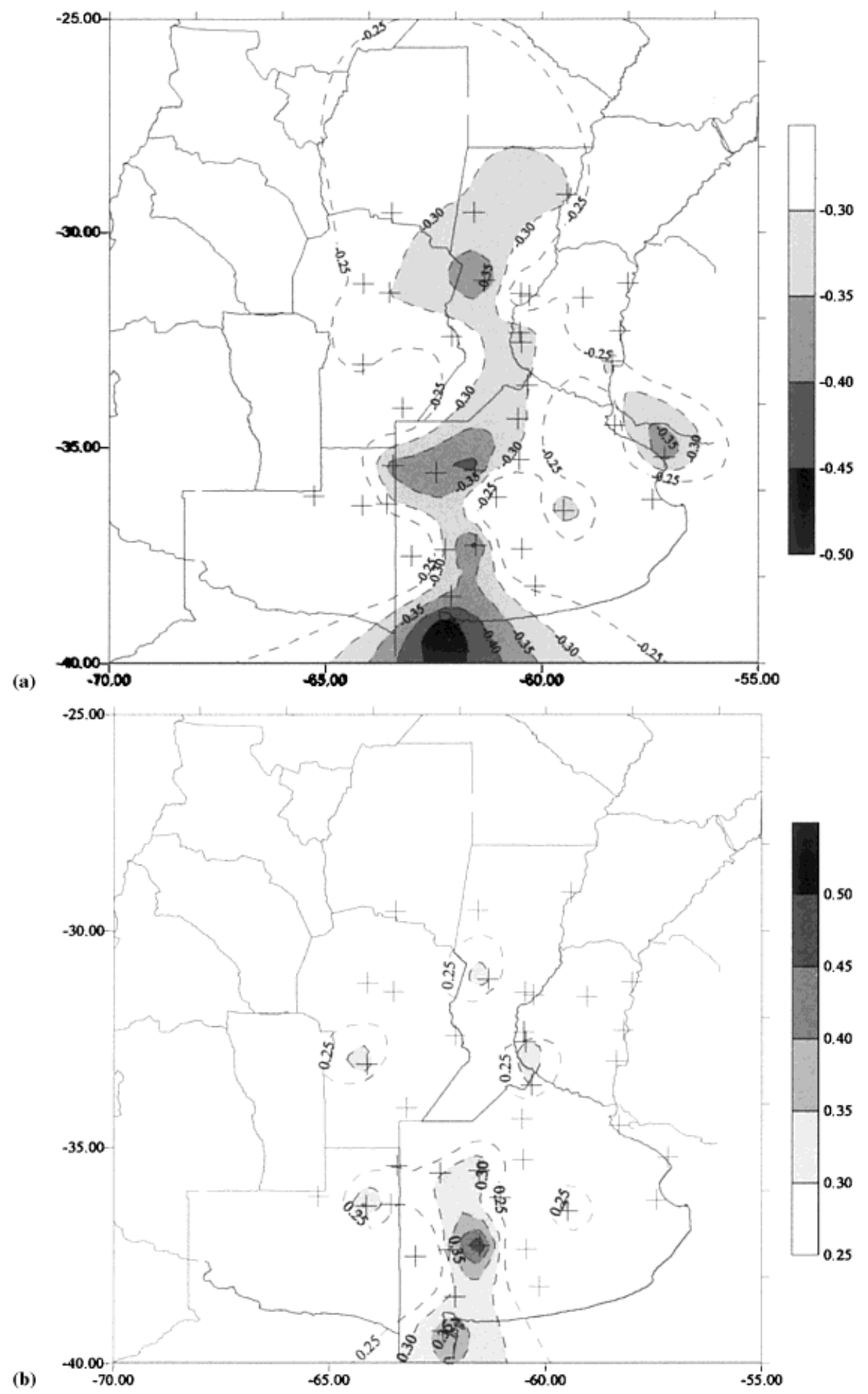

Figure 2. (a) Map of equal correlation contours obtained between the number of frost days during autumn and SST anomalies (Niño 3 region) for the same period, with a $90 \%$ of statistical significance (shaded area). (b) Map of equal correlation contours obtained between the number of frost days during autumn and SOI anomalies for the same period, with a $90 \%$ of statistical significance (shaded area) 
periodicity, as it can be seen in the classification of Quinn (1992), who defined the periods and intensities of EN events (see Table II). In particular, this latter characteristic is important for the present study as the variable used here is strictly connected to the dominant synoptic situation and, therefore, to the circulation, which is affected by EN events (Salles 1998). The existence of a possible connection between the intensity of the warm event (or SO low phase) and the number of frosts was therefore analysed in detail. However, following the definition of warm events (or SO low phase) used by Quinn et al. (1978), they are identified according to the SST in the east of the Equatorial Pacific. Deser and Wallace (1987) showed that SSTs in the eastern Pacific and SO do not always act together. On the other hand, Horel and Wallace (1981) showed that extratropical teleconnections are related to SSTs in the central Pacific (and hence the SO). Taking these elements into account, the classification of Ropelewski and Jones (1987) was also considered in the comparison of the warm events and the number of frosts, making it extensive to the cold event years identified by the same classification (Table III).

In relation to these events, the spatial and temporal distribution of the number of frost occurrences during each month of each year has been studied. A special emphasis has been put on the period 1972-1983, as a detailed study of the circulation of the south of South America is available for that period. This study, performed by Salles (1998) using principal components (PC) methodology, analyses the daily surface pressure fields for annual and seasonal (winter) cycles determining the characteristic patterns and synoptic types frequencies that prevail over Southern South America. The spatial structures of each PC can be understood as different fields that could be grouped in a basic flux (the model that explains most of the variance) and the meridional flux. Within this second group, different models that represent the characteristic fields of the region have been found, three of them can be associated with synoptic situations that could produce frosts. These three models are denoted, following Compagnucci and Salles (1997), as model B (the second in decreasing order of variance, Figure 3(a)), model D (the third or fourth in decreasing order of variance, Figure 3(b)) and model $\mathrm{F}^{-1}$ (the sixth, Figure 3(c)). The total variance explained by them is given in Table IV and denoted as a frost model (FM) and the rest of the models a non-frost model (NFM).

Table II. Quinn's (1992) classification of EN events

\begin{tabular}{ll}
\hline EN events & \\
\hline Period & Intensity \\
\hline M1963-E1964 & Weak \\
1965-1966 & Strong \\
M1968-1969 & Moderate \\
$1972-1973$ & Strong \\
$1976-1977$ & Moderate \\
$1979-1980$ & Weak \\
$1982-$ M1983 & Very strong \\
M1986-1987 & Moderate \\
\hline
\end{tabular}

$\mathrm{M}$ and $\mathrm{E}$ stand for middle and early in the year, respectively.

Table III. Year for which SOI remained above (HSOI) and below (LSOI) 25\% of the distribution for at least 5 months (according to Ropelewski and Jones, 1987)

\begin{tabular}{ll}
\hline HSOI & LSOI \\
\hline 1964 & 1965 \\
1970 & 1969 \\
1971 & 1972 \\
1973 & 1977 \\
1975 & 1982 \\
1988 & 1987 \\
\hline
\end{tabular}


a)



c)



b)



\section{.}

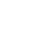
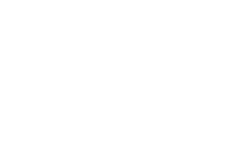
Table IV. Total variance explained by the first six principal components according to Salles (1998)

\begin{tabular}{|c|c|c|c|c|}
\hline \multirow[t]{3}{*}{ Year } & \multirow[t]{3}{*}{ Basic flow } & \multicolumn{3}{|c|}{ Meridional flow } \\
\hline & & \multicolumn{2}{|c|}{ Freezing model } & \multirow[t]{2}{*}{ No freezing model } \\
\hline & & \multicolumn{2}{|c|}{ B model } & \\
\hline \multicolumn{5}{|l|}{ Niño } \\
\hline 1972 & 58.2 & 11.5 & 8.2 & 19.5 \\
\hline 1982 & 60.2 & 10.6 & 7.4 & 20.3 \\
\hline 1976 & 57.1 & 11.7 & 8.7 & 21.2 \\
\hline 1977 & 60.9 & 10.8 & 8.1 & 19.9 \\
\hline 1983 & 60.9 & 11.5 & 8.6 & 19.0 \\
\hline \multicolumn{5}{|l|}{ Niña } \\
\hline 1973 & 64.6 & 10.4 & 6.9 & 17 \\
\hline 1975 & 64.0 & 11.0 & 8.0 & 18.1 \\
\hline \multicolumn{5}{|c|}{ Normal } \\
\hline 1974 & 61.3 & 11.4 & 8.2 & 18.8 \\
\hline 1978 & 60.1 & 9.3 & 6.4 & 20.9 \\
\hline 1979 & 61.1 & 10.9 & 8.0 & 19.2 \\
\hline 1980 & 60.8 & 10.1 & 7.1 & 19.9 \\
\hline 1981 & 61.5 & 10.2 & 7.5 & 19.2 \\
\hline
\end{tabular}

Model D can be related to the situation after the passage of a frontal system with a centre of high pressure located north of $40^{\circ} \mathrm{S}$; this situation produces advection of cold and dry air toward the Continent, although the conditions generated by this model are not as severe as those produced by model B. The explained variance shows a weak variability along the annual cycle (Compagnucci and Salles, 1997).

Model $\mathrm{F}^{-1}$ represents situations associated with a deep low pressure centre located over the southern tip of the Buenos Aires province and the Atlantic Ocean, and an intense anticyclone located over the Pacific Ocean. Synoptic situations represented by this model occur only in winter, therefore its explained variance is very low (Compagnucci and Salles, 1997).

4.1.1. Relationship between frosts and the intensity of EN events. The relationship between the number of frost events and EN episodes is studied here by considering its intensity according to the classification of Quinn (1992). This author studied a long record of ENSO that covers the period from 1497 up to 1990. A classification was obtained using SST anomalies in the east of the Equatorial Pacific and meteorological, hydrological and oceanic considerations, as well as related environmental destruction in coastal communities, ecological consequences and industrial costs to the nation (Quinn et al., 1978, 1987; Quinn, 1992).

A detailed analysis of the available information indicates that the number of frost day results are lower than the climatological value during the occurrence of EN events. This statement remains true only when moderate and intense events are considered, as can be seen in Figure 4(a)-(d). These characteristics are common for most of the cases, however some differences can be noted.

4.1.1.1. Weak events: During weak EN events, according to Quinn (1992) (see Table II: 1963 and 1979-1980), the mean number of frost days was lower than the climatological value (Figure 4(a)). A statistical significance level of $99 \%$ corresponds to the year 1963, although 1979-1980 was non-significant (Figure 4(a)). During the autumn of 1963 (Figure 4(b)), the seasonal mean was above the total mean, although it was non-significant, while for winter and spring the seasonal mean remained below the climatological value with a significance level of $95 \%$ (Figure 4(c) and (d), respectively). Seasonal means during the EN event 1979-1980 do not differ statistically from the mean (with the autumn of 1980 as an exception). 

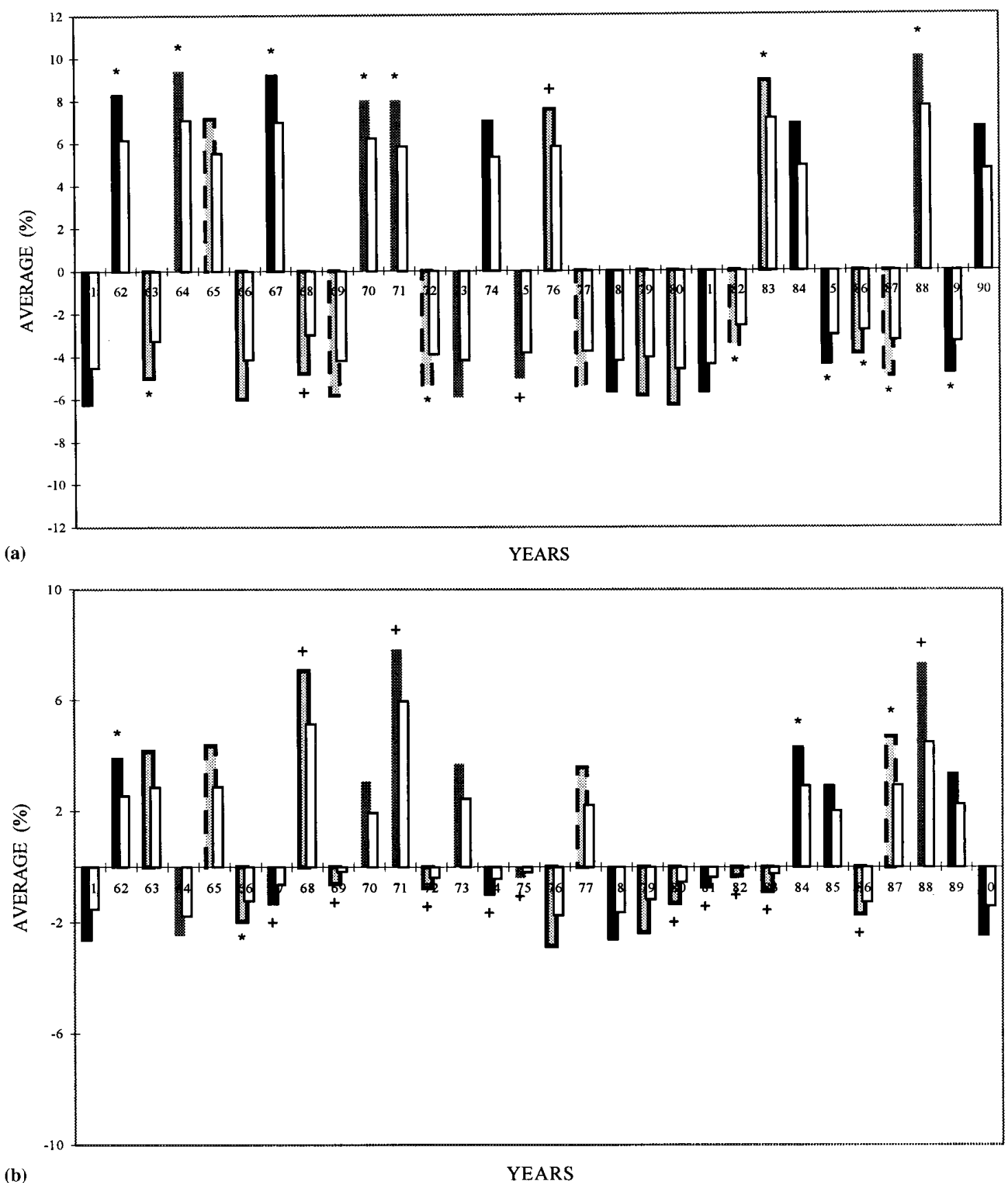

Figure 4. (a) Annual average of days with frosts. Black bars denote Neutral years; dark grey bars are used for LN years (HSOI, Ropelewski and Jones, 1987); light grey bars for EN years according to Quinn (1992), and those with LSOI (Ropelewski and Jones, 1987) are surrounded by dashed lines. The white bars belong to the annual average of days with intense and moderate frosts. The years with a significant level of $95 \%(+)$ and $99 \%\left(^{*}\right)$ are indicated. The climatological annual mean is indicated by a horizontal line.

(b) Seasonal annual averages of days with frosts are indicated for the period March-May. Black bars denote Neutral years; dark grey bars are used for LN years (HSOI, Ropelewski and Jones, 1987); light grey bars for EN years according to Quinn (1992), and those with LSOI (Ropelewski and Jones, 1987) are surrounded by dashed lines. The white bars correspond to the annual season average of days with intense and moderate frosts. The years statistically significative $95 \%(+)$ and $99 \%(*)$ are indicated. The horizontal line indicates the corresponding climatological seasonal mean.

(c) As in Figure 4(b) but for the period June-August.

(d) As in Figure 4(b) but for the period September-November 

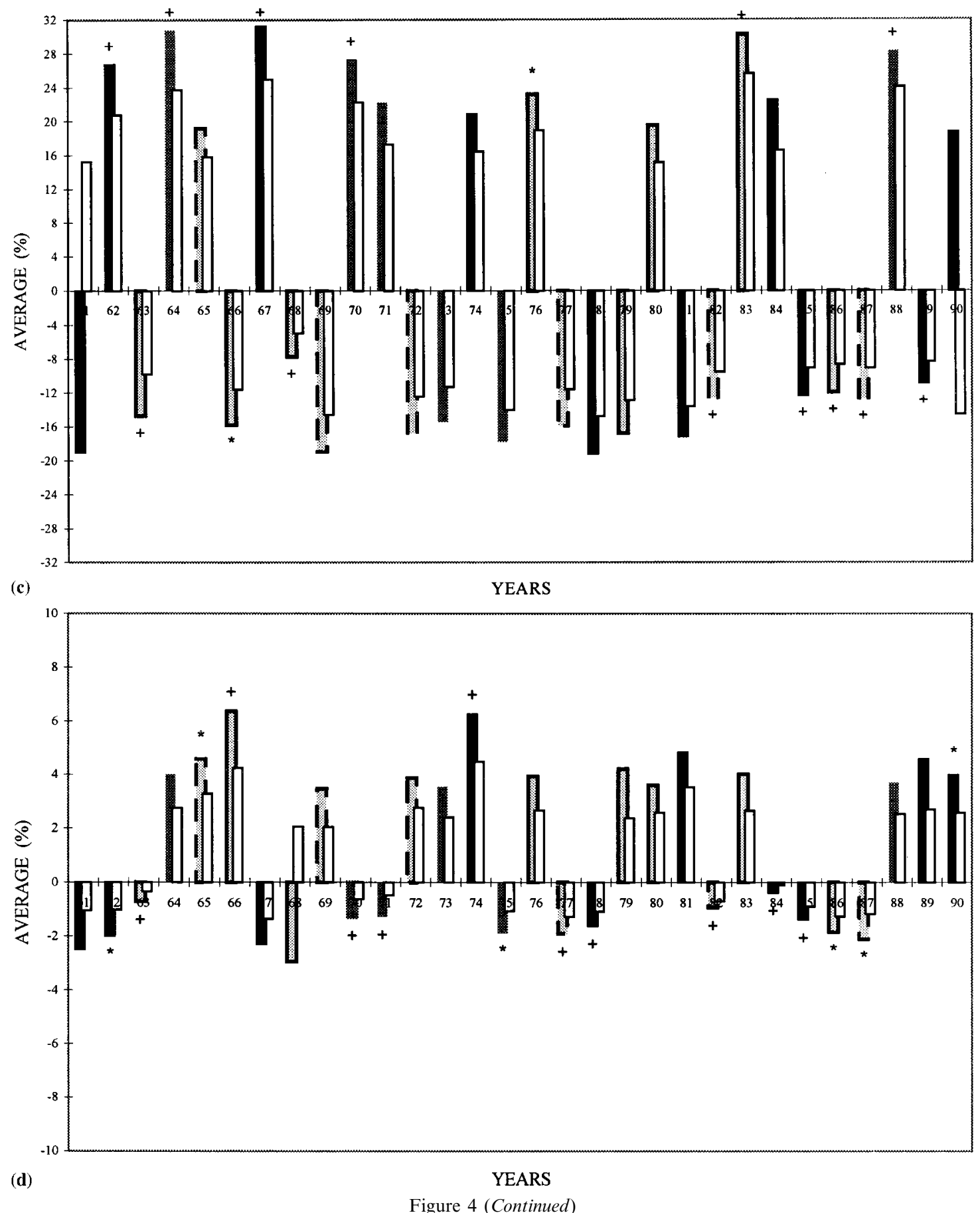

4.1.1.2. Moderate events: For the moderate EN event of 1968-1969 (Table II), the annual mean was lower than the total annual mean with a statistical significance level of $95 \%$ for the first year of the event (Figure 4(a)). The beginning of this ENSO event was registered by the middle of 1968 and the seasonal mean for the autumn of this year was higher than the total seasonal mean, with a significance level of $95 \%$ (Figure 4(b)). Conversely, the rest of the years presented values lower than the corresponding total 
seasonal mean, being especially significant for winter $(95 \%$, Figure $4(\mathrm{c}))$. The number of moderate and intense frost events during the spring was above the corresponding climatological mean, while the total number (weak + moderate + intense) was below its corresponding mean, representing an exceptional case that was not observed for the remaining years of the other seasons. The seasonal mean for the autumn of the following year remained very low $(0.61 \%)$ with a significance of $95 \%$. This number increased considerably during the next winter, remaining below the total seasonal mean for winter and above the total seasonal for spring (both cases non-significant).

The moderate ENSO case of 1986-1987 presented annual and seasonal means below the mean, with a statistical significance level of $99 \%$ (with the autumn of 1987 as an exception).

Another moderate ENSO case occurred during 1976-1977 (Quinn, 1992), but showed particular characteristics. The time evolution of the SOI and the SST within the regions Niño $1+2$ and Niño 3 (Climatic Diagnostics Bulletin, November 1994) presented extremes for the SST for the years 1976 and 1977, a maximum of the SST between June 1976 and January 1977, and SOI minima from July to September, and after March 1977. Therefore, during this event, the SOI was out of phase with respect to the SST anomalies, presenting an anomalous behaviour with respect to the canonical one described by Rasmusson and Carpenter (1982) and Trenberth (1989). Discrepancies among different authors with respect to the intensity of this event can be found in the literature (moderate: Ramage, 1986; Quinn, 1992; Wang, 1995; intense: Estoque et al., 1985; weak: Karoly, 1989), and also with respect to the duration: (Francou and Pizarro, 1985; Ramage, 1986; Karoly, 1989 considered both years, while Rasmusson and Carpenter, 1982; Trenberth, 1984; Fu et al., 1986; Kiladis and van Loon, 1988; Quinn, 1992 took only the year 1976 as EN event).

For southern South America, Salles and Compagnucci (1995) showed that the surface circulation during 1976 was dominated by longer waves, while the circulation during 1977 was more perturbed (a higher variance of shorter wavelengths). With respect to the temperature anomalies, the year 1976 was colder than 1977 for the whole Argentine territory, which is linked to the higher annual mean of frost events for 1976 rather than for 1977; for the first year, the annual mean is significant $(95 \%)$ and it is above the total annual mean (Figure 4(a)). The anomaly pattern structures were similar during for the winters of 1976 and 1977, but with opposite signs. The characteristics of the anomalies can be related to the circulation change between the winters of 1976 and 1977, in particular, the temperature anomalies for those winters clearly reflect the above mentioned circulation change; in 1976 a higher explained variance, associated with synoptic situations characterized by post-frontal anticyclone, was compared to that for 1977 (Table IV). It could explain that, during the winter of 1976 (EN event), a higher number of frost events occurred and the seasonal mean was higher than normal with a significance level of 99\% (Figure 4(c)). Most of the frost events occur mainly during the months of June, July and August, defining the annual mean and resulting in a high value for 1976. The change in circulation from one year to the other is reflected in the autumn (Figure 4(b)) and spring cases (Figure 4(d)), 1976 having the opposite result to 1977 with a significance of $95 \%$.

4.1.1.3. Intense events: The EN event of the years 1972-1973 was considered as an intense one by Quinn (1992), it followed the description of a typical event given by Rasmusson and Carpenter (1982), derived by the composition of those occurring between 1959 and 1976. The anomalies of the SST and the SOI were strictly in opposite phase and the evolution of the warm event was coupled and in phase with the annual cycle (Wang, 1995). According to Salles (1998), the circulation was more perturbed during the warm event (1972) than it was during the cold one (1973). As transient perturbations are responsible for heat exchange in the Southern Hemisphere, it is more important during the winter season when the Pole-Equator temperature gradient is higher, and enhanced by the fact that the ocean temperature of the Equatorial Pacific is higher during the ENSO warm episode (van Loon, 1979). In March 1972, abnormally warm waters reached the Peruvian coasts and, in addition, heavy rains affected this region, suggesting the presence of EN (Cavides, 1975). It can be seen in Figure 4(b) that, during the autumn of 1972 , the frost occurrence mean was lower than the mean value, with a significance of $95 \%$; the same occurred during the winter season and it was higher than the mean during the spring, with these two last cases being non-significant. The number of frost events during 1972 was lower than the mean, with a 
statistical significance of 99\% (Figure 4(a)), but it was also lower for 1973 (non-significant) even when it was a year with a high SOI (HSOI) (Table III). A possible explanation could be given by the values of variance explained by FM (Table IV): the variance for 1972 is higher than that for 1973 and this last, in particular, presented a lower value for model B, responsible for the FM difference between both years.

The winter of 1973 defined a value lower than the climatological mean for this year and, contrasting with the rest of the years, it had a low number of frost events (even lower than that corresponding to 1972), and presented an explained variance value of the basic flow that corresponded to a minimum for this season (Compagnucci and Salles, 1997). However, the annual values of explained variance were 58.5\% and 51.2\% for 1973 and 1972, respectively (Salles and Compagnucci, 1997).

During the intense ENSO event of the years 1965 and 1966, the annual mean varied from values higher than the mean for 1965, to values below this value for 1966, being non-significant in both cases. Seasonal means for the year 1965 remained above the mean for all stations, being statistically significant only for spring $(99 \%)$.

The percentage of frost episodes corresponding to the autumn of the next year was lower than the normal value with a significance of $99 \%$; an identical behaviour has been registered for winter, although spring presented a mean higher than the climatological one with a significance of $95 \%$.

4.1.1.4. Interannual variability: In general, a large variability of frost events was observed from year to year, except for those years between 1977 and 1982 (Figure 4(a)). Compagnucci and Salles (1996) showed, for this period, that there was little interannual variability of the circulation in southern South America. The variance explained by the first PC presents a low interannual variability (from 60 to $62 \%$ ) for the period 1977-1983. This homogeneity in the variance could have originated in the characteristics of the tropical Pacific between 1977 and 1988: the SST was higher than normal and three EN events took place without the compensatory occurrence of LN (Trenberth, 1990). There is more evidence of the circulation change that took place during the late seventies. van Loon et al. (1993) found differences in the sea level pressure in the Southern Hemisphere between the winters of the periods 1972-1977, 1982-1985, and 1987-1989 for mid and high latitudes. Hurrell and van Loon (1994) observed that the semiannual oscillation, the most important in the oceans and Antarctica, weakened after the late seventies. Ebbesmeyer et al. (1991) observed a 'jump' in the Pacific climate after 1976 after studying 40 meteorological, oceanographic and other environmental variables. Wang (1995) showed that there was a change in the characteristics of the beginning of the ENSO events after the warm episode of 1976, relating it with the abrupt change that occurred around 1977. The previous years, in general, would have associated a cold state of the Equatorial Pacific Ocean with a jump to a warm state after 1977. It is reflected in the number of frost events, showing annual and seasonal (autumn and winter) means lower than the total annual mean and the corresponding total seasonal mean, respectively, continuing until 1982 when another ENSO event began to develop. This episode had an atypical development (Cane, 1983; Valdez and Ereño, 1984; Ramage, 1986; Rasmusson, 1987; Trenberth and Shea, 1987; Enfield, 1989, among others): it began in early autumn of 1982 instead of the end of the spring or early summer 1981, as those canonical ENSO events described by Rasmusson and Carpenter (1982), and was, up to that year, the most intense event of the century (as noted by Valdez and Ereño, 1984; Francou and Pizarro, 1985; Hense, 1986; Ramage, 1986; Nobre and Oliveira, 1987; Rasmusson, 1987; Enfield, 1989; Quinn, 1992, among others).

In general, during the year 1982, the circulation was more perturbed than for 1983, with a pressure anomaly increase of 4-5 $\mathrm{hPa}$ with respect to 1982 and a considerably lower temperature, characteristics related to a higher frequency of those systems associated to the advection of polar air by Salles (1998). Considering that model B represents typically this synoptic situation, its explained variance for 1983 was $8.6 \%$ (Table IV), compared to the corresponding variance for 1982 of $7.4 \%$. On the other hand, the addition of the variances of the NFM models (Table IV) was higher for 1982 than for 1983, indicating a greater frequency of synoptic situations not producing frost events during 1982. According to that, the number of frost events was much lower than the total mean during 1982 with a statistical significance of $99 \%$, representing the minimum of the studied period. Conversely, the year 1983 presented a considerable number of frost events, resulting in higher than the total annual mean with a significance of $99 \%$ (Figure 4(a)). The winter anomalies of pressure presented opposite signs for these years and the temperature 
anomalies were remarkably colder for this region during the winter of 1983 (Salles, 1998). It is reflected in the fact that the mean number of frosts was well above the climatological mean for winter with a statistical significance of $95 \%$ (Figure 4(c)). The seasonal number, in general, was inferior to the mean for the autumns of 1982 and 1983 (see Figure 4(b)-(d)). The number of frost episodes increased from the winter of this year and remained high till the spring of the same year, although in a significant way.

4.1.2. Relationship between frosts and EN and LN events. Ropelewski and Jones (1987) defined high SO years as those years during which the Tahiti-Darwin SO index remains in the upper $25 \%$ of the distribution for 5 months or longer, while low SO years were defined as those years during which the SO index remains in the lower $25 \%$ (Table III).

With respect to the opposite phases of the $\mathrm{SO}$, the annual mean was above the climatological mean for four of the six cases identified as HSOI. The exceptions corresponded to LN events of 1973 and 1975, these years presented the least perturbed basic flow of the period 1972-1983, as it can be seen in Table IV, where the first PC presents the highest explained variance values of the 12-year period. The greater persistence of a pattern similar to the basic flow explains the lower Equator-Pole gradient. The number of frost episodes during the autumn of 1975 , followed by a winter with a mean below the total seasonal mean and a spring with the same behaviour, produced a considerably low annual mean. Conversely, for autumn and spring of 1973, the mean was above the climatological one, while it was below for winter. Another feature of the year 1973 is that it was a year with no generalized frost events that could be related to the low explained variance of model B, associated with these kinds of episodes. Also, it presented one of the largest numbers of isolated episodes considerably increasing the annual mean, with respect to the year 1975, that did not necessarily correspond to the typical circulation conditions of FM. During the remaining events with HSOI: 1964, 1970, 1971 and 1988, the seasonal and annual means were higher than the climatological one, with a significance level of $95 \%$ (with 1971 as an exception). The autumn seasonal means for those cold events presented statistically significant high values for 1971 and 1988 (95\%), and lower means (non-significant) for the remaining LN cases. The spring, conversely, presented values higher than normal, but were not statistically significant for the events of 1964 and 1988, while the means were lower than climatological mean for 1970 and 1971 (with a significance of 95\%).

During low SOI (LSOI) years, annual as well as winter seasonal means remained below the corresponding normal values for 5 of the 6 analysed years (Figure 4(a) and (c)).

4.1.3. Frosts during neutral years. All the remaining years in which neither anomalies in the Equatorial Pacific nor extreme values in the phase of the SO were registered, have been classified as neutral $(\mathrm{Ne})$ years (a total of 10). The annual mean was higher than the climatological mean for 5 years $(1962,1967$, 1974, 1984, 1990), and remained lower than this value for the other 5 years $(1961,1978,1981,1985,1989)$. However, the differences with respect to the climatological mean were more important for those cases with a number of frost events higher than normal, with a statistical significance level of $95 \%$ for the years 1962 and 1967 (Figure 4(a)). Seasonal analysis revealed that winters followed the same behaviour of the annual mean, while no systematic behaviour could be established for autumns and springs.

Figure 4(a)-(d) show that the number of moderate and intense frost events and total means follow the same distribution of the total mean and represent a percentage between 60 and $80 \%$ of the total mean. For the particular case of the annual mean (Figure 4(a)), the highest numbers of moderate and intense frost episodes occurred during Ne or LN years (with 1977 as an exception).

4.1.4. Dates of the first and last frost episodes. The dates of the first and last frost episodes of each year have been registered for all meteorological stations and during the period with available information, without considering those years for which missing information could generate unreliable results.

Two groups, the first and last frost episodes, have been determined for each meteorological station and they were subdivided for the calendar year seasons. The number of frosts corresponding to each first and last group has been evaluated for both events of the ENSO cycle and for Ne years (Table V). The dates corresponding to the beginning and end of the warm event, as well as its duration, have been taken into account for this selection. The data could not be tested as the sample is rather small and it is not complete for all stations. 
Table V. Seasons (s: summer, A: autumn, W: winter and S: spring) and number of first and last frosts for EN, LN and Ne years. Values in italics denote stations with incomplete data. The absence of frosts is denoted by a zero and in the case of missing data with a hyphen. Additionally, those years with no frost or a single frost event are indicated.

\begin{tabular}{|c|c|c|c|c|c|c|c|c|c|c|}
\hline \multirow[t]{2}{*}{ Station } & \multirow[t]{2}{*}{ Season } & \multicolumn{3}{|c|}{ First } & \multirow[t]{2}{*}{ Season } & \multicolumn{3}{|l|}{ Last } & \multirow[t]{2}{*}{ A single frost } & \multirow[t]{2}{*}{ No frosts } \\
\hline & & $\mathrm{EN}$ & $\mathrm{LN}$ & $\mathrm{Ne}$ & & $\mathrm{EN}$ & $\mathrm{LN}$ & $\mathrm{Ne}$ & & \\
\hline Reconquista & A & 5 & 2 & 3 & A & - & 0 & 2 & 19681973 & 19821983 \\
\hline $29^{\circ} 11^{\prime} \mathrm{S} 59^{\circ} 42^{\prime} \mathrm{W}$ & W & 5 & 3 & 4 & $\mathrm{~W}$ & 10 & 5 & 6 & 1990 & \\
\hline Ceres & A & 3 & 3 & 10 & $\mathrm{~W}$ & 11 & 6 & 10 & 19771986 & \\
\hline $29^{\circ} 53^{\prime} \mathrm{S} 61^{\circ} 57^{\prime} \mathrm{W}$ & $\mathrm{W}$ & 7 & 3 & 2 & & & & & & \\
\hline Villa María & A & 9 & 6 & 12 & $\mathrm{~W}$ & 9 & 6 & 8 & & \\
\hline $29^{\circ} 54^{\prime} \mathrm{S} 63^{\circ} 41^{\prime} \mathrm{W}$ & $\mathrm{W}$ & 1 & 0 & - & $\mathrm{S}$ & 4 & 0 & 2 & & \\
\hline Córdoba & A & 7 & 5 & 14 & $\mathrm{~W}$ & 13 & 6 & 11 & & \\
\hline $31^{\circ} 19^{\prime} \mathrm{S} 64^{\circ} 13^{\prime} \mathrm{W}$ & $\mathrm{W}$ & 3 & 1 & 0 & & & & & & \\
\hline Pilar & A & 9 & 6 & 14 & $\mathrm{~W}$ & 11 & 6 & 11 & & \\
\hline $31^{\circ} 4^{\prime} \mathrm{S} 63^{\circ} 53^{\prime} \mathrm{W}$ & W & 1 & 0 & 0 & $\mathrm{~S}$ & 2 & 0 & 0 & & \\
\hline Rafaela & $\mathrm{A}$ & 6 & 2 & 13 & $\mathrm{~W}$ & 11 & 6 & 10 & 1982 & \\
\hline $31^{\circ} 11^{\prime} \mathrm{S} 61^{\circ} 33^{\prime} \mathrm{W}$ & W & 2 & 2 & 1 & $\mathrm{~S}$ & 1 & 0 & 1 & & \\
\hline Sauce Viejo & A & 8 & 3 & 9 & $\mathrm{~W}$ & 10 & 6 & 11 & 1982 & 1986 \\
\hline $31^{\circ} 42^{\prime} \mathrm{S} 60^{\circ} 49^{\prime} \mathrm{W}$ & $\mathrm{W}$ & 2 & 2 & 3 & $\mathrm{~S}$ & 1 & 0 & 0 & & \\
\hline Paraná & A & 7 & 5 & 9 & $\mathrm{~A}$ & 1 & - & 0 & 1982 & 19831986 \\
\hline \multirow[t]{2}{*}{$31^{\circ} 47^{\prime} \mathrm{S} 60^{\circ} 29^{\prime} \mathrm{W}$} & $\mathrm{W}$ & 3 & 1 & 2 & $\mathrm{~W}$ & 10 & 5 & 9 & & \\
\hline & & & & & $\mathrm{S}$ & 1 & - & 0 & & \\
\hline Villaguay & $\mathrm{A}$ & 9 & 6 & 10 & $\mathrm{~W}$ & 10 & 4 & 6 & & \\
\hline $31^{\circ} 51^{\prime} \mathrm{S} 59^{\circ} 05^{\prime} \mathrm{W}$ & $\mathrm{W}$ & 2 & 0 & - & $\mathrm{S}$ & 3 & 2 & 3 & & \\
\hline Concordia & A & 6 & 3 & 6 & $\mathrm{~A}$ & 2 & 1 & 1 & 19681978 & 1977 \\
\hline $31^{\circ} 18^{\prime} \mathrm{S} 58^{\circ} 01^{\prime} \mathrm{W}$ & W & 3 & 3 & 1 & $\mathrm{~W}$ & 7 & 4 & 5 & 19851986 & \\
\hline C. del Uruguay & $\mathrm{A}$ & 6 & 3 & 8 & $\mathrm{~W}$ & 9 & 5 & 8 & 1986 & \\
\hline $32^{\circ} 29^{\prime} \mathrm{S} 58^{\circ} 2^{\prime} \mathrm{W}$ & $\mathrm{W}$ & 3 & 2 & 1 & & & & & & \\
\hline Gualeguaychu & A & 8 & 5 & 12 & $\mathrm{~W}$ & 12 & 6 & 10 & & \\
\hline $33^{\circ} \mathrm{S} 58^{\circ} 37^{\prime} \mathrm{W}$ & $\mathrm{W}$ & 3 & 1 & - & $\mathrm{S}$ & 1 & 0 & - & & \\
\hline Oliveros & A & 9 & 5 & 13 & $\mathrm{~W}$ & 10 & 5 & 10 & & \\
\hline $32^{\circ} 33^{\prime} \mathrm{S} 60^{\circ} 51^{\prime} \mathrm{W}$ & W & 1 & 1 & - & $\mathrm{S}$ & 3 & 1 & 1 & & \\
\hline Rosario & A & 9 & 6 & 13 & $\mathrm{~W}$ & 10 & 6 & 10 & & \\
\hline $32^{\circ} 55^{\prime} \mathrm{S} 60^{\circ} 47^{\prime} \mathrm{W}$ & W & 2 & 0 & 0 & $\mathrm{~S}$ & 3 & 0 & 1 & & \\
\hline Marcos Juarez & $\mathrm{A}$ & 8 & 6 & 14 & W & 8 & 4 & 7 & & \\
\hline $32^{\circ} 42^{\prime} \mathrm{S} 62^{\circ} 09^{\prime} \mathrm{W}$ & W & 1 & 0 & - & $\mathrm{S}$ & 5 & 2 & 4 & & \\
\hline Río Cuarto & $\mathrm{A}$ & 8 & 3 & 12 & W & 12 & 6 & 10 & & \\
\hline $33^{\circ} 07^{\prime} \mathrm{S} 64^{\circ} 14^{\prime} \mathrm{W}$ & W & 3 & 3 & - & $\mathrm{S}$ & 1 & 0 & - & & \\
\hline Laboulaye & A & 9 & 6 & 15 & $\mathrm{~W}$ & 9 & 6 & 6 & & \\
\hline $34^{\circ} 08^{\prime} \mathrm{S} 63^{\circ} 22^{\prime} \mathrm{W}$ & & & & & $\mathrm{S}$ & 4 & 0 & 4 & & \\
\hline Pergamino & A & 7 & 5 & 14 & $\mathrm{~W}$ & 9 & 4 & 8 & & \\
\hline $33^{\circ} 56^{\prime} \mathrm{S} 60^{\circ} 33^{\prime} \mathrm{W}$ & $\mathrm{W}$ & 1 & 0 & - & $\mathrm{S}$ & 2 & 2 & 3 & & \\
\hline Junin & A & 8 & 6 & 14 & $\mathrm{~W}$ & 11 & 5 & 8 & & \\
\hline $34^{\circ} 33^{\prime} \mathrm{S} 60^{\circ} 55^{\prime} \mathrm{W}$ & $\mathrm{W}$ & 2 & 0 & 0 & $\mathrm{~S}$ & 2 & 1 & 2 & & \\
\hline Ezeiza & $\mathrm{A}$ & 8 & 5 & 14 & $\mathrm{~W}$ & 8 & 5 & 9 & & \\
\hline $34^{\circ} 49^{\prime} \mathrm{S} 58^{\circ} 32^{\prime} \mathrm{W}$ & W & 1 & 1 & 0 & $\mathrm{~S}$ & 5 & 1 & - & & \\
\hline San Miguel & $\mathrm{A}$ & 8 & 6 & 13 & W & 12 & 6 & 11 & & \\
\hline $34^{\circ} 33^{\prime} \mathrm{S} 58^{\circ} 44^{\prime} \mathrm{W}$ & W & 2 & 0 & 1 & $\mathrm{~S}$ & 1 & 0 & 0 & & \\
\hline El Palomar & A & 7 & 6 & 13 & A & - & 0 & 1 & & \\
\hline \multirow[t]{2}{*}{$34^{\circ} 36^{\prime} \mathrm{S} 58^{\circ} 36^{\prime} \mathrm{W}$} & $\mathrm{W}$ & 2 & 0 & 0 & $\mathrm{~W}$ & 10 & 6 & 9 & & \\
\hline & & & & & $\mathrm{S}$ & 1 & 0 & 1 & & \\
\hline Castelar & A & 8 & 6 & 13 & W & 11 & 5 & 11 & & \\
\hline $34^{\circ} 4^{\prime} \mathrm{S} 58^{\circ} 39^{\prime} \mathrm{W}$ & W & 2 & 0 & 1 & $\mathrm{~S}$ & 2 & 1 & 0 & & \\
\hline Punta Indio & $\mathrm{A}$ & 5 & 3 & 9 & W & 9 & 6 & 6 & 1986 & 19771978 \\
\hline $35^{\circ} 22^{\prime} \mathrm{S} 57^{\circ} 17^{\prime} \mathrm{W}$ & $\mathrm{W}$ & 3 & 2 & 1 & $\mathrm{~S}$ & 2 & 0 & - & & \\
\hline Dolores & A & 8 & 6 & 13 & W & 5 & 2 & 4 & & \\
\hline $36^{\circ} 21^{\prime} \mathrm{S} 57^{\circ} 44^{\prime} \mathrm{W}$ & & & & & $\mathrm{S}$ & 6 & 4 & 6 & & \\
\hline
\end{tabular}


Table V. (Continued)

\begin{tabular}{|c|c|c|c|c|c|c|c|c|c|c|}
\hline \multirow[t]{2}{*}{ Station } & \multirow[t]{2}{*}{ Season } & \multicolumn{3}{|c|}{ First } & \multirow[t]{2}{*}{ Season } & \multicolumn{3}{|c|}{ Last } & \multirow[t]{2}{*}{ A single frost } & \multirow[t]{2}{*}{ No frosts } \\
\hline & & EN & $\mathrm{LN}$ & $\mathrm{Ne}$ & & EN & LN & $\mathrm{Ne}$ & & \\
\hline Azul & & & & & A & 0 & 0 & 1 & & \\
\hline \multirow[t]{2}{*}{$36^{\circ} 45^{\prime} \mathrm{S} 59^{\circ} 5^{\prime} \mathrm{W}$} & A & 8 & 6 & 14 & W & 4 & 0 & 3 & & \\
\hline & W & 1 & 0 & - & $\mathrm{S}$ & 9 & 6 & 7 & & \\
\hline Nueve de Julio & A & 7 & 6 & 14 & W & 11 & 5 & 10 & & \\
\hline $35^{\circ} 27^{\prime} \mathrm{S} 60^{\circ} 53^{\prime} \mathrm{W}$ & W & 3 & 0 & 0 & $\mathrm{~S}$ & 2 & 1 & 1 & & \\
\hline Bolivar & A & 9 & 5 & 11 & W & 10 & 4 & 7 & & \\
\hline $36^{\circ} 15^{\prime} \mathrm{S} 61^{\circ} 06^{\prime} \mathrm{W}$ & & & & & $\mathrm{S}$ & 2 & 2 & 2 & & \\
\hline Pehuajo & A & 10 & 5 & 13 & W & 7 & 4 & 7 & & \\
\hline $35^{\circ} 52^{\prime} \mathrm{S} 61^{\circ} 54^{\prime} \mathrm{W}$ & W & 0 & 1 & - & $\mathrm{S}$ & 6 & 2 & 3 & & \\
\hline Trenque Lauquen & A & 6 & 3 & 10 & W & 9 & 3 & 7 & & \\
\hline $35^{\circ} 58^{\prime} \mathrm{S} 62^{\circ} 44^{\prime} \mathrm{W}$ & W & 1 & - & - & $\mathrm{S}$ & 1 & 1 & 1 & & \\
\hline General Pico & A & 9 & 6 & 15 & W & 9 & 4 & 5 & & \\
\hline $35^{\circ} 42^{\prime} \mathrm{S} 63^{\circ} 45^{\prime} \mathrm{W}$ & & & & & $\mathrm{S}$ & 3 & 2 & 6 & & \\
\hline Victorica & A & 10 & 5 & 12 & W & 6 & 2 & 5 & & \\
\hline $36^{\circ} 13^{\prime} \mathrm{S} 65^{\circ} 26^{\prime} \mathrm{W}$ & & & & & $\mathrm{S}$ & 6 & 3 & 5 & & \\
\hline Santa Rosa & $\mathrm{s}$ & 0 & 0 & 1 & W & 5 & 2 & 4 & & \\
\hline $36^{\circ} 34^{\prime} \mathrm{S} 64^{\circ} 16^{\prime} \mathrm{W}$ & A & 9 & 6 & 14 & $\mathrm{~S}$ & 8 & 4 & 7 & & \\
\hline Anguil & $\mathrm{s}$ & 0 & 1 & 1 & W & 1 & 0 & 2 & & \\
\hline \multirow[t]{2}{*}{$36^{\circ} 3^{\prime} \mathrm{S} 63^{\circ} 59^{\prime} \mathrm{W}$} & A & 10 & 5 & 12 & $\mathrm{~S}$ & 11 & 5 & 7 & & \\
\hline & & & & & $\mathrm{s}$ & 0 & 1 & - & & \\
\hline Bordenave & $\mathrm{s}$ & 0 & 0 & 1 & W & 3 & 0 & 4 & & \\
\hline $37^{\circ} 51^{\prime} \mathrm{S} 63^{\circ} 01^{\prime} \mathrm{W}$ & A & 10 & 6 & 13 & $\mathrm{~S}$ & 10 & 6 & 7 & & \\
\hline Pigue & $\mathrm{s}$ & 0 & 0 & 1 & W & 1 & 0 & 0 & & \\
\hline $37^{\circ} 36^{\prime} \mathrm{S} 62^{\circ} 23^{\prime} \mathrm{W}$ & A & 10 & 6 & 12 & $\mathrm{~S}$ & 12 & 6 & 11 & & \\
\hline Coronel Suarez & A & 9 & 4 & 13 & W & 2 & 1 & 3 & & \\
\hline $37^{\circ} 26^{\prime} \mathrm{S} 61^{\circ} 53^{\prime} \mathrm{W}$ & & & & & $\mathrm{S}$ & 8 & 4 & 7 & & \\
\hline Laprida & A & 9 & 5 & 13 & W & 2 & 1 & 2 & & \\
\hline $37^{\circ} 34^{\prime} \mathrm{S} 60^{\circ} 46^{\prime} \mathrm{W}$ & & & & & $\mathrm{S}$ & 10 & 5 & 8 & & \\
\hline Tres Arroyos II & A & 7 & 5 & 11 & W & 3 & 1 & 2 & & \\
\hline $38^{\circ} 2^{\prime} \mathrm{S} 60^{\circ} 15^{\prime} \mathrm{W}$ & & & & & $\mathrm{S}$ & 8 & 5 & 7 & & \\
\hline Bahía Blanca & $\mathrm{s}$ & - & 0 & 2 & W & 3 & 1 & 3 & & \\
\hline $38^{\circ} 44^{\prime} \mathrm{S} 62^{\circ} 1^{\prime} \mathrm{W}$ & A & 9 & 6 & 11 & $\mathrm{~S}$ & 10 & 5 & 7 & & \\
\hline Hilario Ascasubi & A & 8 & 5 & 10 & W & 2 & 1 & 1 & & \\
\hline $39^{\circ} 23^{\prime} \mathrm{S} 62^{\circ} 37^{\prime} \mathrm{W}$ & & & & & $\mathrm{S}$ & 8 & 4 & 8 & & \\
\hline
\end{tabular}

The first frost event occurred between the end of the summer and the beginning of the autumn for those stations located in the south of Pampa Húmeda region, for the centre of this region during the autumn and for the stations in the north and northeast of the region during the winter. The periods corresponding to the above mentioned sub-regions were compared with the dates of the first frost event in EN and LN years. The first frost date was logically delayed for EN cases, it occurred during the winter instead of during the autumn as it did for most meteorological stations in Ne years. No apparent delay is observed in Table $\mathrm{V}$ for those stations located in the northeast and southwest of the region, although it is observed when analysing the data series of each particular station. An analogous behaviour was observed in LN years, although presenting an earlier first frost date.

Differences in the dates corresponding to the last frost event have not been observed for EN, LN and Ne years. On the other hand, those years in which no frost events occurred corresponded mostly to EN years, the remaining years with these characteristics were identified as $\mathrm{Ne}$, and all cases corresponded to stations located in the northeast of the studied region. 


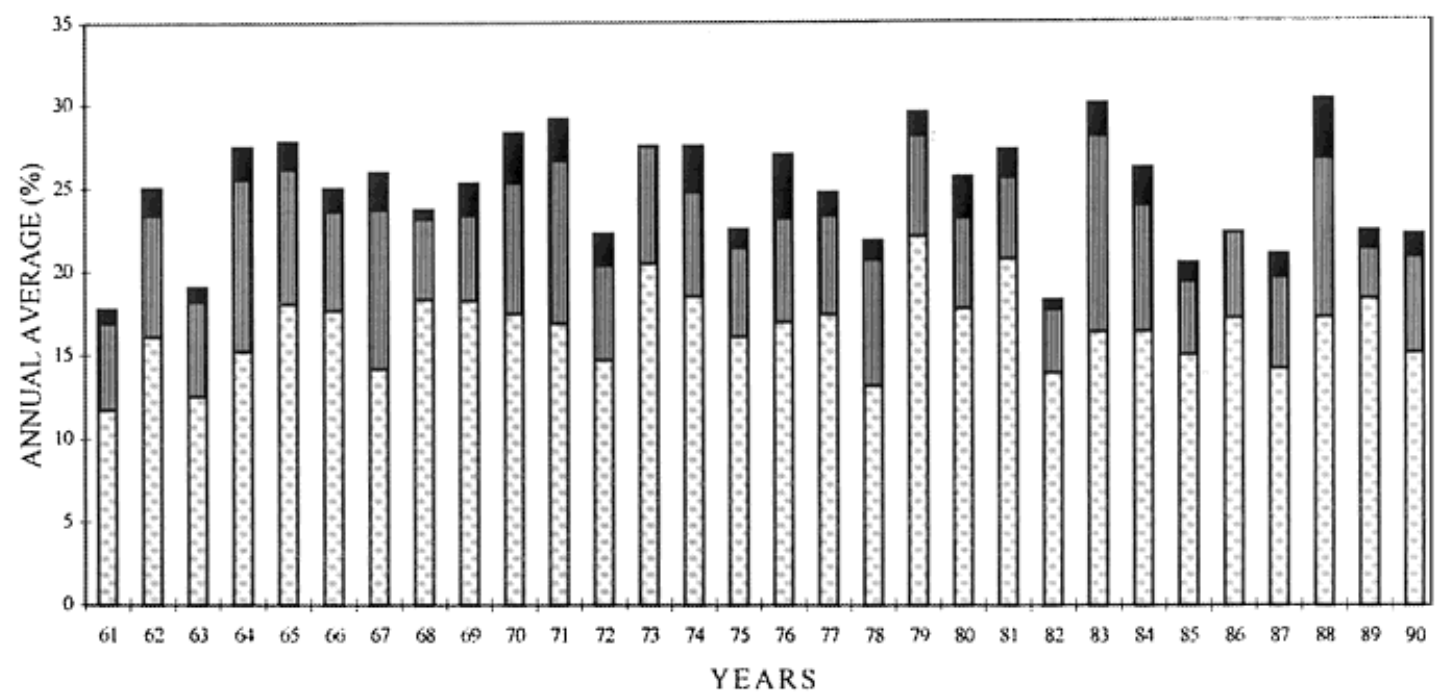

Figure 5. Mean number of isolated (dotted), partial (stripes) and generalized (black) frosts occurred in a time period of 1 year

\subsection{Spatial analysis}

The behaviour of the frost episodes classified according to the affected area (isolated, partial, generalized) has been analysed. As seen in Figure 5, during the entire period considered, isolated events were more frequent than partial ones and partial events were more frequent than generalized episodes. The largest number of partial frost events was registered during 1964, 1971, 1988 (HSOI years), 1967 and 1983. Generalized events were less frequent, in particular, none were registered during the years 1973 and 1986 (both EN years), while during 1963, 1968, 1982 (also EN events), they occurred with very low frequency.

The monthly mean spatial distribution of frequencies for each year is given in Figure 6. A great variability can be observed between months and years. Isolated events prevailed for most of the months with high interannual variability. This behaviour was also observed for partial events; they were restricted to shorter periods (in general, from May to September) than for isolated episodes. The number of months per year affected by generalized episodes is between 2 and 4, although it can vary between 0 and 5 . Examples of the first case are the years 1976 and 1986 (both are first years of a moderate EN event), and 1977 is an example of the last case, also an EN year.

Analysing those years identified as EN, LN and Ne separately, it can be seen that for this last group, the percentage of meteorological stations affected by frost episodes varied between 22 and $28 \%$. The annual values for EN years are in the 18-30\% interval and between 23 and $31 \%$ for LN years. Even when these results suggest that EN years present the smaller amplitude, it must be noted that the smallest corresponds to 1982, an event classified as very intense (according to Quinn, 1992), and the largest corresponds to the 1979 weak event (Quinn, 1992). Some authors do not consider the latter as a warm episode (Ropelewski and Jones, 1987; Kiladis and Días, 1989). Both events presented the largest (1979) and the lowest (1982) number of isolated frost episodes, if they are compared with those that occurred in the rest of the period.

\section{CONCLUSIONS}

The relationship between ENSO cycles and frost episodes has been studied for the first time in the present paper. For this variable, the region is teleconnected with ENSO events exhibiting opposite behaviour for warm and cold phases, as it results with other meteorological variables such as temperature and pressure 
(Kiladis and Días, 1989). Results show that for EN years, the annual mean was below the total mean (climatological) for at least 1 of the 2 years in which the warm event takes place. As the interannual variability of the studied variable is large, a clear relationship between the intensities of the frost episodes and the ENSO event could not be found.

The three most carefully studied EN cases were 1972/1973, 1976/1977 and 1982/1983, each one with particular characteristics as noted by Wang (1995) and by Salles (1998). They concluded that the atmospheric circulation changes in southern South America could be associated to the flow pattern changes and/or changes in their frequencies, as every month of the year presents the same synoptic types independently of the season. The occurrence, or non-occurrence, of frost events is related to this change in the occurrence frequencies of the synoptic types, although other factors such as the persistence or local and regional effects must be considered.

The LSOI coincides with those years for which the number of frost episodes was below the climatological mean, with the year 1965 as an exception. Conversely, during the HSOI, the annual mean was above the total annual mean in four of the six cases, according to the classification of Ropelewski and Jones (1987). An identical relationship has been observed for winter seasonal means, as the occurrence of frost episodes during this season defines the sign of the annual mean in all cases, with 1980 being the exception. The transition seasons, particularly spring, did not present a systematic behaviour.

The spatial distribution presents a high monthly and interannual variability for all the categories (isolated, partial and generalized). However, the only years during which no frost events occurred coincide with moderate EN events.
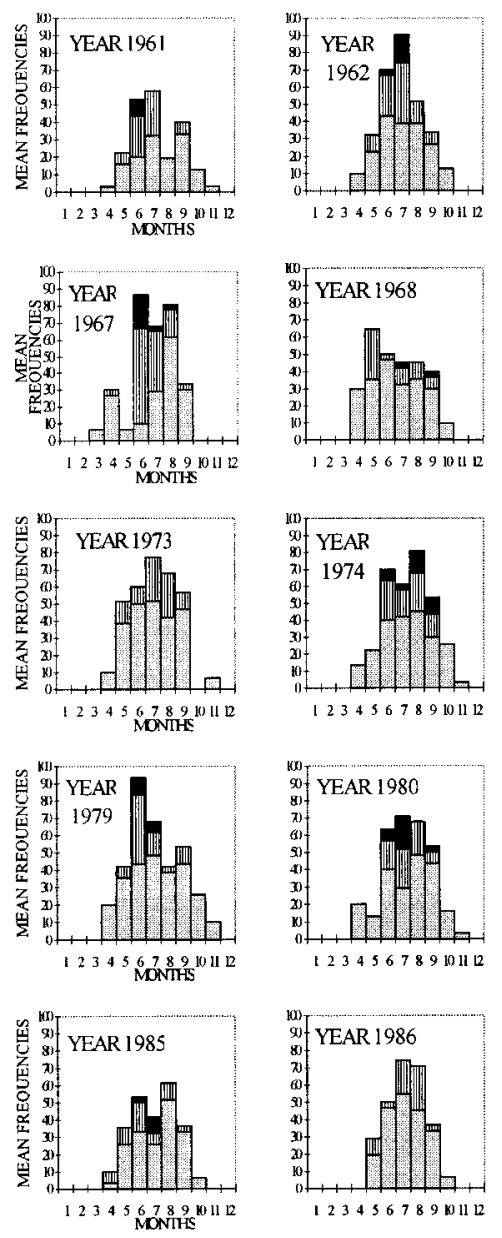
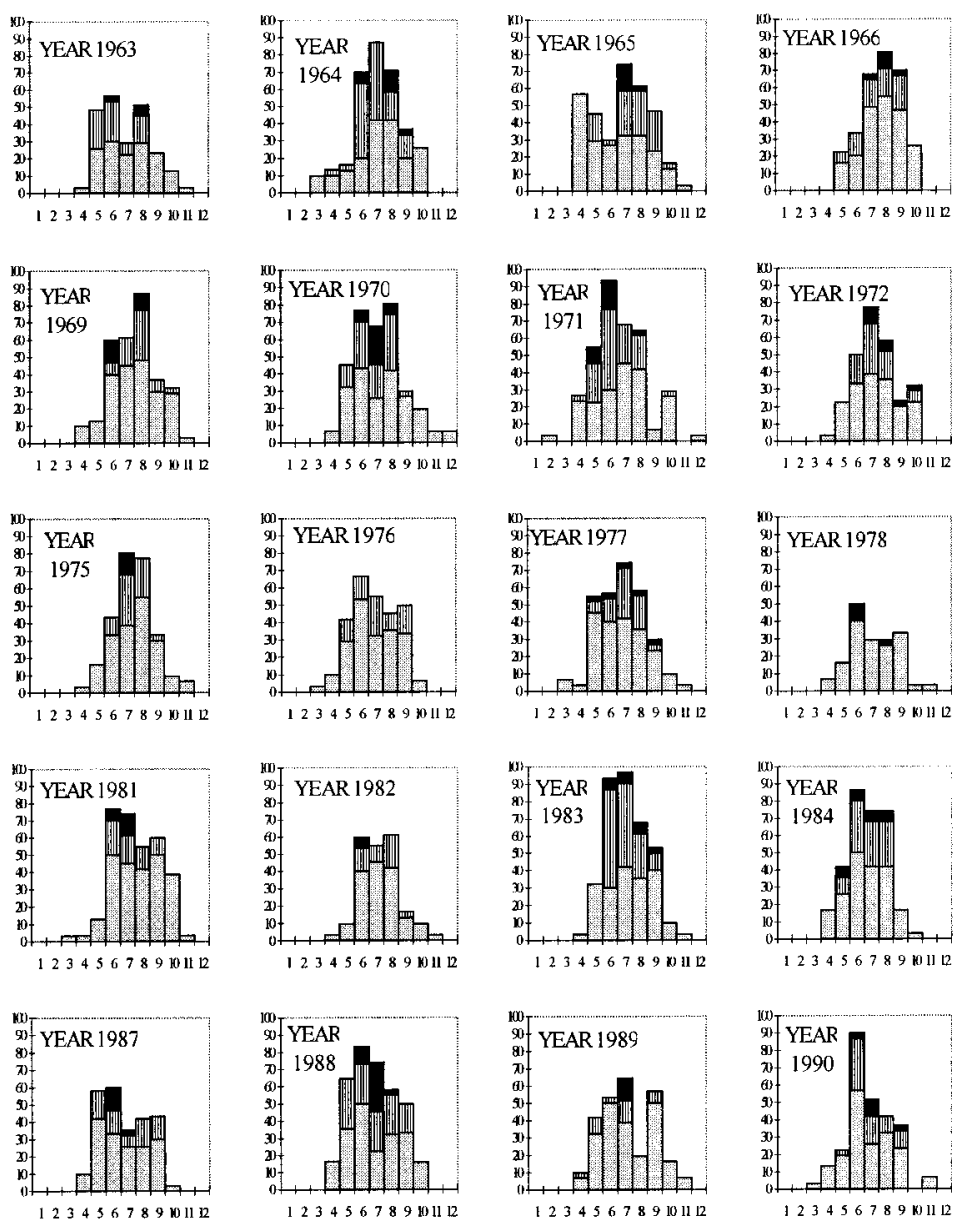

Figure 6. Isolated (dotted), partial (stripes) and generalized (black) monthly mean frequencies (\%) over the studied area 
Results corresponding to the first and last frost event coincide with the correlations, as no relationship between SST or SOI and the frost frequency could be found for spring in any of the meteorological stations of the region, neither is the date of the last frost event modified by the occurrence of a warm or cold event. Conversely, for autumn and winter, a significant correlation has been found between the ENSO indices and the number of frost events for some meteorological stations. The corresponding correlation for the last case is more important, and the date of the first frost event is delayed for EN years and occurs before for LN years. This fact, and the number of frost episodes observed during the different seasons of the year, would indicate a link between the frost occurrence and the state of development of the warm episode, with a greater impact for autumn and winter, for which the cold event seems to have greater influence.

It is concluded that, even when the frost episodes are regional phenomena, processes operating at much larger scales such as the LSOI/HSOI produce an impact in the central region of Argentina. Even when this impact is difficult to quantify, it explains part of the frequency variability within the Pampa Húmeda region, linking frost occurrence and the state of development of the warm episode. The impact is greater for autumn and winter months for which the cold event seems to have greater influence; conversely this degree of association is not observed for spring months.

\section{ACKNOWLEDGEMENTS}

The authors wish to thank CONICET and Universidad de Buenos Aires (project D1/TW22) for financial support. We also want to thank Dr Alejandra Salles for useful discussions.

\section{REFERENCES}

Aceituno P. 1988. On the functioning of the Southern Oscillation in the South American sector. I: surface climate. Monthly Weather Review 116: $505-516$.

Barros V, Castañeda ME, Doyle M. 1996a. Recent precipitation trends in southern South America to the east of the Andes: an indication of a mode of climatic variability. Greenhouse gas emissions under developing countries point of view. In Proceedings of Latin-America Workshop on Greenhouse Gas Emission of Energy Sector and their Impacts, Rosa LP, dos Santos MA (eds). COPPE/UFRJ: Río de Janeiro, Brazil; 41-67.

Barros V, Casteñada ME, Doyle M. 1996b. Variabilidad interanual de la precipitación: señales del ENSO y del gradiente meridional hemisférico de temperatura. In Anales VII Congreso Argentino de Meteorología. VII Congreso Latinoamericano e Ibérico de Meteorología. Centro Argentino de Meteorólogos (CAM) and Federación Latinoamericana e Ibérica de Sociedades de Meteorología (FLISMET): Buenos Aires; 321-322.

Barros V, Scasso LM. 1994. Surface pressure and temperature anomalies in Argentinean connection with Southern Oscillation. Atmósfera 94: 159-171.

Berri GJ. 1996. Practical application of statistical modelling of seasonal to interannual climate variability to environmental problems in South America. Anais Academia Brasileira de Meteorologia 68(1): 223-238.

Cane MA. 1983. Oceanographic events during El Niño. Science 222: 1189-1195.

Cavides CN. 1975. El Niño 1972: its climatic, ecological, human, and economic implications. The Geographical Review 65: $493-505$.

Compagnucci RH, Salles MA. 1996. Comportamiento temporal y espacial de los campos de presión de superficie en el sur de Sudamérica para los años 1972-1983. In Anales VII Congreso Argentino de Meteorología. VII Congreso Latinoamericano e Ibérico de Meteorología. Centro Argentino de Meteorólogos (CAM) and Federación Latinoamericana e Ibérica de Sociedades de Meteorología (FLISMET): Buenos Aires; 345-346.

Compagnucci RH, Salles MA. 1997. Surface pressure patterns during the year over southern South America. International Journal of Climatology 17: 635-653.

Climatic Diagnostics Bulletin. 1994. Climate Analysis Center, November. US NOAA/NWS/NMC, 6 and 9.

Deser C, Wallace JM. 1987. El Niño events and their relation to the Southern Oscillation: 1925-1986. Journal of Geophysics Research 92(14): 189-196.

Ebbesmeyer CC, Cayan DR, McLain DR, Nichols FH, Peterson DH, Redmond KT. 1991. 1976 step in the Pacific climate: forty environmental changes between 1968-1975 and 1977-1984. In Proceeding of the Seventh Annual Pacific climate (PACLIM) Workshop. California Department of Water Resources. In: Interagency Ecological Studies Program Technical Report, vol. 26, Betancourt JL, Tharp VL (eds); 115-126.

Enfield DB. 1989. El Niño, past and present. Reviews of Geophysics 27: 159-187.

Estoque MA, Luque J, Chandeck-Monteza M, Garcia J. 1985. Effects of El Niño on Panamá rainfall. Geofisica Internacional 24: $355-381$.

Francou B, Pizarro L. 1985. El Niño y la sequía en los Andes Centrales: (Perú y Bolivia). Bulletin L'Institut Français de D'Estudes Andines XIV: $1-18$.

Fu C, Diaz HF, Fletcher JU. 1986. Characteristics of the response of sea surface temperature in the Central Pacific associated with warm episodes of the Southern Oscillation. Monthly Weather Review 114: 1716-1738. 
Grimm AM. 1997. Impact of Southern Oscillation on rainfall over Southern Brazil. In Fifth International Conference on Southern Hemisphere Meteorology and Oceanography, 7-11 April. Pretoria, South Africa. American Meteorological Society: Boston, MA; $230-231$.

Halpert MS, Ropelewski CF. 1992. Surface temperature patterns associated with the Southern Oscillation. Journal of Climate 5: $577-593$.

Hense A. 1986. Multivariate statistical investigations of the northern hemisphere circulation during the El Niño event 1982/1983. Tellus 38A: 189-204.

Horel JD, Wallace JM. 1981. Planetary scale atmospheric phenomena associate with the Southern Oscillation. Monthly Weather Review 109: 813-829.

Hurrell WL, van Loon H. 1994. A modulation of the atmospheric annual cycle in the Southern Hemisphere. Tellus 46A: 325-338.

Karoly DJ. 1989. Southern Hemisphere circulation features associated with El Niño-Southern Oscillation events. Journal of Climate 2: $1239-1252$

Kiladis GN, van Loon H. 1988. The Southern Oscillation. VII: meteorological anomalies over the Indian and Pacific sectors associated with the extremes of the Oscillation. Monthly Weather Review 116: 120-136.

Kiladis GN, Días HF. 1989. Global climatic anomalies associated with extremes in the Southern Oscillation. Journal of Climate 2: 1069-1090.

Minetti JL, Vargas WM. 1997. Interaction processes between the annual wave and the disturbances in series of daily temperature. Journal of Climate 10: 297-316.

Nobre CA, Oliveira AS. 1987. Percipitations and circulation anomalies in South America and the 1982-1983 El Niño/Southern Oscillation episode. In Conference on Geophysical Fluid Dynamics with special emphasis on 'El Niño', Kayano MT, Nobre CA (eds). Sao José dos Campos: Brazil; 325-328.

Pittock AB. 1980. Patterns of climatic variation in Argentina and Chile-II: Temperature, 1931-1960. Monthly Weather Review 108: $1362-1369$.

Quinn WH, Zopf DO, Short KS, Kuo Yang RTW. 1978. Historical trends and statistics of the Southern Oscillation, El Niño, and Indonesian droughts. Fisheries Bulletin 76: 663-678.

Quinn WH, Neal VT, Antunez de Mayolo SE. 1987. El Niño occurrences over the past four and a half centuries. Journal of Geophysics Research 92(13): 14449-14461.

Quinn WH. 1992. A study of Southern Oscillation-related climatic activity for AD 622-1990 incorporating Nile River flood data. In El Niño: Historical and Paleoclimatic Aspects of the Southern Oscillation, Diaz HF, Markgraf V (eds). Cambridge University Press: Cambridge; $119-149$

Ramage CS. 1986. El Niño. Scientific American June: 76-83.

Rasmusson EM, Carpenter TH. 1982. Variations in tropical sea surface temperature and surface wind fields associated with the Southern Oscillation/El Niño. Monthly Weather Review 110: 354-383.

Rasmusson EM. 1987. Meteorological Aspects of the El Niño-Southern Oscillation phenomenon. In Conference on Geophysical Fluid Dynamics, Kayano MT, Nobre CA (eds). Sao José dos Campos: Brazil; 46-89.

Ropelewski CF, Jones PD. 1987. An extension of the Tahiti-Darwin Southern Oscillation Index. Monthly Weather Review 115: $2161-2165$.

Ropelewski CF, Halpert MS. 1996. Quantifying Southern Oscillation-precipitation relationship. Journal of Climate 9: 1043-1059.

Salles MA, Compagnucci RH. 1995. Características de la circulación de superficie durante 1976-1977 y su relación con las anomalias en el sur de Sudamérica. Meteorológica 1-2(20): 7-16.

Salles MA, Compagnucci RH. 1997. Características de la circulación de superficie durante el período diciembre de 1971- febrero de 1974 y sus relaciones con las anomalías ENOS en el sur de Sudamérica. Meteorológica 1(22): 35-48.

Salles MA. 1998. La circulación atmosférica de superficie en el sur de Sudamérica y su relación con las anomalías de temperatura y precipitación. Tesis Doctoral, Departamento de Ciencias de la Atmósfera, FCEyN, UBA; 158.

Tanco R, Berri GJ. 1996. Acerca del efecto del fenómeno del Niño sobre la precipitación en la Pampa Húmeda Argentina. In Anales VII Congreso Argentino de Meteorología. VII Congreso Latinoamericano e Ibérico de Meteorología. Centro Argentino de Meteorólogos (CAM) and Federación Latinoamericana e Ibérica de Sociedades de Meteorología (FLISMET): Buenos Aires; $319-320$.

Trenberth KE. 1984. Signal versus noise in the Southern Oscillation. Monthly Weather Review 112: 326-332.

Trenberth KE, Shea DJ. 1987. On the evolution of the Southern Oscillation. Monthly Weather Review 115: $3078-3096$.

Trenberth KE. 1989. Toga and atmospheric processes. In Understanding Climate Change, Geophysics Monograph 52. IUGG 7: 117-125, Berger A, Dickinson RE, Kidson JW (eds).

Trenberth KE. 1990. Recent observed interdecadal climate changes in the northern hemisphere. Bulletin of the American Meteorological Society 71: 988-993.

van Loon H. 1979. The association between latitudinal temperature gradient and eddy transport. I: transport of sensible heat in winter. Monthly Weather Review 107: 525-534.

van Loon H, Kidson JW, Mullan AB. 1993. Dacadal variation of the annual cycle in the in the Australian Data Set. Journal of Climate 6: $1227-1231$

Valdez AJ, Ereño CE. 1984. El fenómeno denominado 'El Niño' y las inundaciones del Paraná. Informe Organización Techint 235: $29-75$.

Vargas WV, Penalba OC, Minetti JL. 1999. Las precipitaciones mensuales en zonas de la Argentina y el ENOS. Un enfoque hacia problemas de decisión. Meteorológica 1-2(24): 3-22.

Wang B. 1995. Interdecadal changes in El Niño onset in the last four decades. Journal of Climate 8: 267-285. 